\title{
Accounting for Difference: A Comparative Look at the Autobiographical Travel Narratives of Hazin Lāhiji and 'Abd-al-Karim Kashmiri
}

\author{
Mana Kia \\ Harvard University
}

\begin{abstract}
This paper examines the mid-eighteenth century historical memoir of Mohammad Ali Hazin Lāhiji and the auto-biographical travel narrative of 'Abd al-Karim Kashmiri as a way to understand a shared tradition of cultural conceptions and textual borrowing, even in the midst of different attributions of historical meaning and valuations within that culture. Hazin often serves as an iconic figure, representative of the changing relationship between Iran and Hindustan in the eighteenth century. Reading Hazin's memoir in relation to Kashmiri's travels with Nadir Shah's army from Delhi to Iran on his way to hajj problematizes this dominant reading. Underneath diverging and sometimes conflicting claims in these texts, history is represented in a way that evinces similar ideas of home, country, and ideal political rule in the context of travel and exile.
\end{abstract}

\section{Keywords}

Hazin, Kashmiri, fall of the Safavids, Indian travelers to Iran, Nadir Shah's invasion of India, Persian culture

Shaikh Mohammad 'Ali Lāhiji (1692-1766), known as Hazin, was born in Isfahan and spent almost three decades of his life seeking knowledge, an activity that entailed a great deal of travel. Educated by the luminaries of Isfahan and Shiraz, he lost most of his family and wealth in the Afghan invasion. Afterwards, he traveled incessantly in western and central Iran, Mesopotamia, and Arabia, never remaining in one place for more than a couple of years. His alleged involvement in the assassination of Nāder Shah's governor in Lar resulted in his voyage to Hindustani domains in $1734 .{ }^{1}$ He spent various periods of time

${ }^{1}$ I use the term Hindustan because it is the term my sources use to refer to the kingdom ruled by the Mughals, a geographical reference to central north India that was the seat of that empire; it provides distinction from the modern colonial geographical concept of the Indian subcontinent or the nation-state evoked by the word 'India.' For the same reasons I use the term Iran instead of Persia, referring specifically to former Safavid domains, which cover some regions now part of other 
in Sindh and the Punjab, particularly in Lahore. After a notorious decade in Delhi, where he alienated many political and literary elites, Hazin resettled in Benares in the year of the Mughal emperor Mohammad Shah's death (1748) and lived out the rest of his days there. ${ }^{2}$ Scholars generally foreground Hazin's denigration of all things Hindustani, yet his memoir, Tazkerat al-ahvāl, deals with Hindustan in less than a fifth of the text. Often overlooked is that most of Hazin's memoir is concerned with and structured by the fall of the Safavid state and the rise of Nāder Shah in the ensuing turbulence. ${ }^{3}$ The memoir narrates a life of travels, deeply intertwined with the historical events of its time, which is ultimately a text of involuntary migration, a representation of a life lived ethically, in spite of the cruelties of fate and the pain of exile.

'Abd-al-Karim Kashmiri (d. 1784), a resident of Delhi at the time of Nāder Shah's conquest of the city in 1739, accompanied Nāder's army back to Iran via Transoxiana, in service as a functionary (motasaddi). ${ }^{4}$ He parted ways with Nāder's army in Qazvin in 1741 and in the company of 'Alavi Khan, who had joined the army in Delhi as Nāder's head physician (hakim-bāshi), made his way to the Iraqi shrine cities and then onto Hejaz to perform hajj. He returned to Hindustan via a ship to Bengal in 1742 and settled in Delhi. Bayān-e Vãqe (hereafter, Bayān) provides an account of the high politics of Mughal domains from a Delhi-based, Mughal-centric perspective. ${ }^{5}$ The text circulated widely in Persian and English language circles, as evinced by multiple Persian manuscript copies in India, Iran, and Britain and its translation into English soon after the text's completion. ${ }^{6}$ Bayān is primarily a history, with an autobiographical

nation-states. I use the term Persian in a much broader cultural sense. In this paper, there are both Irāni and Hindustani Persians, though the majority of literate people were at least bilingual.

2 He was revered as a saint by local people during his life and afterwards (Khatak, pp. 101-04, 116-17). On Hazin's life and work, see Khatak and Shafi i-Kadkani.

${ }^{3}$ Most monographs draw on the text as a source of factual information, but do not engage critically with the source itself. As they are mining the text for facts, their main concern is the reliability of the information within, not its meaning. See Lockhart; Axworthy; Tucker.

${ }^{4}$ Little is know of Kashmiri's early life. Since forty-five years lapse between Nāder's invasion and Kashmiri's death, it is unlikely that he was older than his mid-thirties. For more on Kashmiri, see Shafi.

5 Alam and Subrahmanyam note that the section of the text from the death of Mohammad Shah in 1748 is likely written by Mohammad Bakhsh, also known as Āshub, an early copyist and admirer of Kashmiri (289-90). I have treated the text as a single entity because this is the form in which the text circulated and my analysis does not depend on unitary authorship of the text. The text, as outlined by Kashmiri in the introduction, was to have a different ending that Kashmiri never provided. Instead, Âshub continued to add the events of high Mughal politics in an ongoing fashion. Each manuscript seems to have ended at a different date in the late eighteenth and even early nineteenth century. The published version I have quoted from in this chapter ends in $1193 / 1779$.

6 The shoddy English translation by Francis Gladwin, The Memoirs of Khoja Abdulkurreem, 
travel narrative of pilgrimage ( hajjnamma) nested within. A detailed overview of the work has been provided elsewhere (Alam and Subrahmanyam, pp. 24790). Kashmiri's account is drawn from his own observations, buttressed by past written histories (such as Hazin's), and orally transmitted information of contemporaries he deemed reliable, such as 'Alavi Khan, Mirzā 'Ali Akbar (in whose service he was) and others of Nāder's entourage (Lockhart, p. 301). Hazin's text, whose historical account of the fall of the Safavids and Nāder Shah's rise Kashmiri draws from, is also made up of oral and written accounts of others, in addition to his own. Both texts incorporate accounts from Iranian and Hindustani informants, making it somewhat difficult to call either text a discrete view of Iran or Hindustan, as if such things were mutually exclusive. These texts are the products of multiple regionally diverse voices, edited and mediated by their respective authorial voices but not reducible to them. ${ }^{7}$

Scholars often interpret Hazin's views of India as a representative form of Iranian proto-nationalism, assuming a modern, anachronistic signification of what Iran, and being from Iran, means. ${ }^{8}$ Hazin's view of Hindustan as iconic of something identifiable as an "Iranian" view of Hindustan is grossly oversignified. Moreover, it obfuscates overlapping ideas of exile, home and the importance of specific historical events to the changing shape of Persianate culture, which for the Iranians of the first half of the eighteenth century was the fall of the Safavid state. ${ }^{9}$ Though relations do change between Irāni and

was published in Calcutta $(1788,1812)$ and London (1793). Gladwin excludes the first section $(b \bar{a} b)$ on the fall of the Safavids, the rise of Nāder Shah and his invasion of Hindustan, as well as the events occurring after the death of Mohammad Shah. The sections pertaining to the politics of Hindustan after Kashmiri's return are also greatly abridged. The better translation is by Francis Pritchard, in manuscript form at the British Museum (Add. 30,782). The early date of this translation is likely due to the English (and European) fascination with Nāder Shah, as Kashmiri's text was primarily understood to be a history of the invasion and the weakening of Hindustan.

7 We cannot assume that the narrative self-representation is equivalent to Hazin's subjective identity. Even in post-romantic Euro-American contexts, reading an autobiographical text as the straightforward reflection of the individual author is problematic. See de Man, pp. $920 \mathrm{f}$.

8 Alam and Subrahmanyan call Hazin "a later grumbler" and link certain expressions and attitudes in his text to ones written by travelers from Iran to Hindustan, the Deccan and Thailand decades and even centuries earlier, erasing generic specificities and wider authorial and textual contexts (2007, pp. 175-242). They present this "Iranian" view of Hindustan as a type of Orientalism, a concept adopted from Cole.

9 Some scholars point to the lack of patronage for poets caused by the decline of central Mughal power, but lack of patronage is part of a broader set of events. The changing stakes of migration were also affected by their contexts of origin. The importance of the fall of the Safavids explains the particularly acute lamentations of home and exile resulting from a loss of home in the temporal, not just geographical sense. See Alam and Subrahmayam 2007; Sharma 2003. 
Hindustani Persians, they share particular notions of home and exile, as well as understandings of geographical and political concepts that shape their differing regional identities. Though historical changes resulted in new regional configurations and a concomitant fracturing of the Persianate world, a continuing common cultural repository made possible textual borrowings that expressed differing, and sometimes conflicting, attributions of cultural valuation and historical meaning. ${ }^{10}$

In order to show why something might be virtuous or base, just or tyrannical, both Hazin and Kashmiri narrate their often conflicting views in similar ways that demonstrate a shared repository of values and meanings, derived from the common Persianate cultural storehouse. Part of the elementary curriculum for any literate Persian is Sa di's Golestān, ${ }^{11}$ and it is no surprise that this text, like many others, is both a repository of adab (style, manners) and akbläq (morals). The essence of the Persianate is contained in the two, an ethics of social comportment wherein one's manners or style ( $a d a b)$ is a direct manifestation of one's morals (akhläq), both of which together are indivisible as ethics, the performance and embodiment of morality and masculinity. ${ }^{12}$ This notion governs the sensibilities that shape the possibilities of representation that are at the heart of the Persianate. Transmitted through a Persian education (though also disseminated outside the Persian language), ${ }^{13}$ this shared ethical language of the Persianate made possible literary and textual borrowings that could be made to express diverging, and sometimes conflicting, claims using the same relative ethical valuations of loyalty and justice.

In these texts, home appears as a series of concepts-multiple, shifting and only sometimes geographically rooted. Iran and Hindustan, as geographically defined polities, were not always the increments in which the idea of home was measured. These kingdoms were also envisioned as entities made up of smaller regions with their own histories, geographical character, cultural practices and administrative organization. As far as geography and culture were concerned, Iran was less than Persian and Persian was more than Iran. ${ }^{14}$ Home

10 It is this common culture, beyond just a shared linguistic heritage, that enabled Persianate culture to localize in accommodation of conflicting regional concerns. Idiomatic localization has always been a part of Persian literary culture. The purpose of Persian dictionaries from the earliest time was to explain regionally specific idiomatic usages to broader audiences (Kinra 2008a).

11 See Thackston's bilingual edition. Sa 'di's Bustān was also a primary text for poetry. A common secondary text was often Nasir-al-Din Tusi's Akhlāq-e Nāseri. For more about this curriculum, as well as the significant participation of Hindus in Persian culture in Hindustan, see Alam and Subrahmanyam 2004.

12 For more on adab and ethics, see Loewen; Metcalf; Richards; O’Hanlon.

13 This occurs through Persian speakers who are bi- or multilingual (Kia).

${ }^{14}$ It is problematic to assume that most in the Safavid heartlands spoke Persian as their first 
was also a morally rooted concept, and the absence of just rule and ethical conduct, whether by overthrow or decline, ${ }^{15}$ resulted in a lament characterized by a shared understanding of an ideal society. Home was the presence of friends and peers, and the social comfort such intimacies provided, and their lack made up a similarly envisioned sense of exile. A person's relationship to home was constituted differently by specific historical events. The continuing common means by which these localizations of Persianate culture were articulated continued through the eighteenth century, distinguishing fracturing from dissolution. Francis Robinson qualifies his discussion of the decline of what he calls Perso-Islamic culture by emphasizing that Persian was never as widespread throughout the Subcontinent as it was in the eighteenth century (Robinson, pp. 112-14). ${ }^{16}$ Noting the decline of Mughal power, and thus centralized patronage, the rise of regional vernaculars, and of Urdu as a poetic language, Robinson emphasizes that these were only emerging challenges to Perso-Islamic culture. Scholars seeking to write genealogies of later outcomes have overemphasized their importance in the eighteenth century. Telling cultural history as the becoming of nation-states "sacrifices eighteenth century realities to twentieth century concerns" (Robinson, pp. 121-22).

\section{Remembering the Safavids: Hazin, Hindustan and the Meaning of Home}

Hazin was a specific type of exile, a refugee from catastrophic events that he perceived to have destroyed both his home and any future hope of access to it. His historical memoir was written in Delhi, in the aftermath of Nāder Shah's invasion of Hindustan, just as he had secured financial resources to set himself up as a man of independent means and substance in the city. ${ }^{17}$ The text func-

language. The language of the military court was Turkish and some elite and many social groups in Iran at this time spoke Turkish as a first language but were often educated in Persian or were able to speak it. Because of its prestige, many Persian speaking elites acquired some ability to speak Turkish. Some form of Turkic or regional languages like Kurdish, Baluchi, Gilaki, and Mazandarani was the vernacular for the majority of the inhabitants of Iran in the eighteenth century. See Perry 2001.

${ }^{15}$ By decline I mean actual political power. Mughal political legitimacy remained intact until the early nineteenth century and formed the framework of political rule within which both regional rulers and the British East India Company saw themselves. See Travers.

${ }_{16}$ The use of Perso-Islamic as a descriptor of Persianate culture in Hindustan is problematic largely because it fails to account for the many non-Muslims who participated within it, such as the many Hindu monshis. See Kinra 2008b.

${ }^{17}$ Hazin did not give the text a title, nor was it known by one when it circulated in the eighteenth century. The most recent Persian publication (Tehran, 1996) of this text has re-titled it as Târikh o safarnāma-ye Hazin (Hazin's History and Travelogue). The earliest edition was pub- 
tions as a statement of self within the circles of Delhi literati, just as it seeks to specifically distinguish him from their number. ${ }^{18}$ In contrast, Kashmiri was a pilgrim, traveling with the army that sacked the Mughal imperial city and brought its ruler low. Though he perceived the disorder and political chaos as the decline and dishonor of his home, Kashmiri wrote the text after returning home. In spite of these different writing contexts, both texts idealize the past and lament the present according to their particular takes on history. Hazin states that his text is meant as a warning ('ebrat), to preserve memory (yajdgār), and to alleviate the pain of exile (Hazin, p. 144). ${ }^{19}$ Specifically, Hazin remembers and gives meaning to Iran under Safavid rule, and this meaning, together with the fall and irretrievable material and cultural destruction of Safavid Iran, is what defines him as a poetic persona, as "Hazin." This exaltation of Safavid Isfahan stands in implicit contrast to his authorial location in Mughal Delhi. Similarly, Kashmiri, as a resident of the Mughal imperial capital, defines himself according to the exalted nature of the realm and all it stands for, in contrast to the victorious, yet base and ignoble Iranian ruler Nāder Shah.

For both Kashmiri and Hazin, the ruler is a metonym for the character of a realm, just as an imperial city is a metonym for the whole of the land. Their affiliation with imperial cities is indivisible from affiliation to rulers of their respective empires, and thus the empire itself. The jewels of these imperial seats, the monarchs, gave character to their cities, as articulations of regnal self-representation giving feature to a place through the act of rule. From the perspective of the imperial city, this character emanated outwards, imbuing the whole empire. ${ }^{20}$ For those from the capital, their homeland overlapped directly with their sense of loyalty to a particular monarch and all he stood for, and through him, what the realm stood for. Hazin and Kashmiri share this affiliation with the imperial city as a perfected representation of the character of the entire realm as empire. And affiliation with the imperial city meant affiliation with the character of the monarch and his dynasty that ruled from that city.

lished (London, 1831) as Târikh-e ahvāl: ba tazkera-ye hāl-e Mawlānā Shaykh Mohammad 'Ali Hazin (History of conditions: Memoir of the times of H.).

${ }^{18}$ Hazin and the context of post-Nāder Delhi are discussed at length in my forthcoming dissertation. The information regarding the position and function of Hazin's memoir is drawn from Ārzu's entry on Hazin (Ārzu, I, pp. 379-86).

19 Hazin also notes that he wrote his account in the space of two nights when he was unable to sleep or concentrate on anything, and that the writing eased his "disturbed heart and mind (del o demägh-e shurida)" (262).

20 This is a view from the center and while local elites from other domains (mamälek) within the empire might participate with the ruling culture, this character also came into contact and sometimes tension with locally derived self-conceptions of place. 
The rough trajectory of Hazin's closely intertwined account of his life and the larger historical circumstances is in three phases. The first outlines his youth, situating his family and early life through social connections and education. Places are described at length through the men of learning who inhabit them. There is a symbiotic relationship between physical environment and moral state manifested in the ethical intercourse of its inhabitants. ${ }^{21}$ Hazin narrates the province of Gilān as a land of beauty and purity, in which an inner and outer harmony is mirrored in the state and conduct of the inhabitants, who are both noble-mannered and learned. ${ }^{22}$ Noble manners are a sign of learning, often the same thing as high levels of morality, reflecting a concept of learning that combines formal education with spiritual knowledge-the exterior and interior of knowledge. As he reaches adulthood, ${ }^{23}$ Hazin travels to Fārs to continue his studies and describes the places through his acquisition of friends and knowledge. ${ }^{24}$ Home is thus characterized by the presence of the learned and upright, whose noble manners make possible the intimacies of friendship. When he returns from Fārs to Isfahan at the behest of his father, Hazin spends time with his family and friends. He calls these visits and interactions, "among the precious blessings of life" (némathā-ye garān-māya) (pp. $191 \mathrm{f}$.). This dual acquisition of friendship and knowledge in the travels of his early life is punctuated by experience of and musing on carnal love (and ultimately its rejection) as well as the rejection of marriage (an endeavor separate from love). The emotional and physical celibacy he chooses are a necessary part of his spiritual, morally upright quest for knowledge, and is telling of the ways in which "noble-mannered" and "learned" actually signify in relation to each other for Hazin.

The second phase of his trajectory begins with the Afghan invasion of Iran, leading to the siege of Isfahan, and the hardships and mayhem that followed. Hazin lost his whole family and most of his friends in the siege of Isfahan and the upheavals of the following years. From this point, the larger political landscape of the times is first mentioned and closely woven in with Hazin's personal trajectory, indicating its effect on his life. Hazin alternates from section to section, on the movement of armies, fighting of battles, and his own movements and actions. It is during this period that the account is

${ }^{21}$ He describes Isfahan as the quintessential great city, as he travels in its circles of great and learned men in the course of his education (pp. 163-65).

22 Both of these attributes are of course only accorded to the upper strata, though the common people are described as virtuous. Gilān is his father's birthplace, as well as source of family income (pp. 167-68).

${ }^{23}$ This majority is reached at age twenty, a common age for young men to take leave of their families and set out on their own to further their educations through travel.

${ }^{24}$ For instance, see his description of Shiraz, pp. 177-80. 
most like an elegy, its lament for the Safavids and all they represented culturally and morally, layered into a lament for all his dead friends and family, who are narrated as the cream of late-Safavid society. Again we see the intermeshed nature of the personal with the larger world, the inner quality of morality and spirituality and the outer manifestation of order and harmony, as well as the heightened sense of glory and beauty of the past and the grief over the death and disorder of the present.

After years of upheaval all over the country, an instability reflected in Hazin's own constant motion, the Afghans are repelled largely through the military abilities of Tahmāsp Qoli Khan (1698-1747), ${ }^{25}$ later Nāder Shah Afshār, who then brings the rest of former Safavid domains under his control by expelling the Russians and Ottomans as well. But instead of the restoration of the Safavid government, and thus the spiritual restoration of the land of Iran, Nāder Shah's rapacious governors set upon the already ravaged people. Hazin's occasional involvement in politics is presented as self-sacrifice of spiritual integrity for the greater good of the populace's welfare. He moves from place to place, lamenting the sad state of the country and cannot bring himself to settle down. Hazin's account of oppression of the people of Làr at the hands of Nāder's governor are indicative of this sad state (pp. 245-47). The events that lead to the governor's assassination are narrated as a breach of etiquette, a violation of ethical behavior, not just of a governor in relation to the common people, but also to the prominent elite (pp. 248-51). It is Hazin's suspected involvement in this assassination (which he vehemently denies) that makes his presence in Nāder Shah's Iran untenable. After unsuccessfully attempting to live in Kerman incognito, finding the roads to the Iraqi shrine cities blocked by Nāder's wars, and ignoring the urging of an English captain to go to Europe, Hazin sets out for Hindustan.

The third phase of his trajectory is marked by his flight to Hindustan. From the time he arrives in Sindh, the pitch of Hazin's laments grows more fevered. We are given only a skeletal account of his movements in Hindustan, with no narration of his interactions with people. During his stay in upper Sindh, he states that "seeing this domain (mamlakat) any more is extremely abhorrent (makruh)" and that he has no patience to write of the happenings of his time in this region (diār; p. 261). In fact, he goes so far as to declare, "I do not count the time of my residence in this domain as part of my life" (p. 260). Instead, Hazin offers a vast historical account of the treacherous and base ethical behavior of Mughal rulers toward Safavid rulers, a manifestation of

25 There is some disagreement about Nāder's date of birth; some give it as early as 1688 . Lockhart provides a persuasive reason for why the latter date is more likely (p. 291 n. 1). 
Hindustan's degraded spiritual nature that Hazin extends to its culture and people, via the land.

Hazin begins by outlining how Bābor, the first Mughal king, benefited all his life from the continual support and friendship of Shah Esmāi il, the first Safavid king, whom Hazin likens to Solomon. It is only with this aid that Bābor was able to gain the throne of Hindustan, since by his time the constant bickering of the Timurid princes among themselves and the tyranny practiced on the people had left their domains (Khorasan and Transoxiana) in a pitiable state. Bābor, in appropriate acts of friendship, duly acknowledged the centrality of Safavid aid to his fortunes. Bābor's children and grandchildren also sought aid (which was, of course, granted) from the Safavids in times of helplessness and need, but they always neglected to reciprocate. This is a dual betrayal of the relationship established by their forefather, and of their own friend, the Safavid king. This negligence is a serious breach of faith and demonstrates the base character of Mughal kings, just as it demonstrates the superior substance of the Safavids, who continue to offer aid whenever it is requested, in spite of the lack of appropriate response (Hazin, pp. 270-71). This dichotomous dynastic evaluation also serves as an evaluation of the respective realms of Iran and Hindustan, with the monarch giving meaning to his domain. Hazin elaborates that when times were troubled in Iran but tranquil in Hindustan, the Mughal king's friendly

manner changed to one of abundant haughtiness and pride; they barred the path of friendship (rāh-e āshnä $i$ masdud dāshtand), and this practice ('ädat) has been established in the nature of Bābor's line. Apparently, the prevalence of this manner is from the effects of Hindustan's water and climate, since it is apparent that the people of these regions do not seek friendship without selfish intentions (Hazin, pp. 271-72).

The betrayal of Hindustani kings shows Hindustan as ethically lesser than Iran by virtue of this behavior, a flaw resulting from a quality that permeates and pollutes the very air and water. Hazin links duplicitous and self-interested behavior, a sign of ignoble virtues, to the land, and states that such behavior on the part of the rulers of Hindustan $(r \vec{a} y \bar{a} n)$ toward the Persian kings (moluk-e 'Ajam) predates Islam. Whenever these Persian kings, rulers of Irän-zamin (the land of Iran), ${ }^{26}$ approached Hindustan with an army, the Hindustanis, recognizing their inability to prevail, became greatly humble and weak and were

26 This linkage of 'Ajam with Iran and Turān (Transoxiana) underlines the origin of this culture, dating from pre-Islamic times; it weakens the Mughal claim to be equal participants of this culture via the Ghaznavids and the Timurids. 
submissive tributaries in every way. When these Persian commanders returned to Iran, after a short time those Hindustani rulers of turbid judgment (tira-ra $\vec{a} i)^{27}$ would be seduced by the pressures of those around them for esteem and a fistful of coins. They would be overtaken with the presumption of pride, forget their promises and change their behavior, ranging about in their land full of false and empty boastings (Hazin, p. 272). This basic paradigm, repeatedly fulfilled in the past and the present, becomes the character-bestowing nature of the respective lands themselves. Relations between the Safavids and Mughals become the most recent fulfillment of pre-Islamic dynastic relations between Irani and Hindustani rulers in the Shähnama. ${ }^{28}$ And so this ancient Iranian kingship, distinguished by the ethical comportment and military might of its kings, is shaped by the qualities of the land and manifested in the behavior of the people. This paradigm is brought to bear on Hazin's present, where the lack of a proper ruler has left Iran in a state of disarray, in contrast to Hindustan, where the qualities of the land preclude a noble ruler. This painstaking attempt to set Iran and Hindustan in opposition to one another could only be provoked by a general acceptance of the idea of these two realms as socially and culturally affiliated, just as their kings have a long history as friends and peers.

Hazin is also attempting to recoup the fall of the Safavids as a result not of weakness, but of betrayal and a general discordance of fate, where everything has been turned upside down. The fall of Iran and his forced exile in Hind become a story of friendship betrayed. Hazin narrates Iran as the ever-selfless friend, true to the obligations of aid, exchange and support, while Hindustan is the selfish friend, of fair-weather loyalty, inconstant and heedless of obligations (Hazin p. 274). Hazin notes that Hindustan did nothing to help its friend Iran when the latter was beset by the Afghans, laying part of the blame on Hindustan for the fall of the Safavids. With the Afghan invasion and the assumption of Shah Tahmāsp II to the throne, when "all that tumult spread in the provinces, as was the manner of the Hindustani king, the ritual of inquiring [after the Shah's well-being] (rasm-e porseshi) never crossed his mind, rather he observed the way of acquaintance and amity with Mir Vays the Afghan” (Hazin, p. 274). The cause for the failure of the Safavids to hold the throne and right the situation of their kingdom is not their own deficiency, but their

27 This could also be read as a reference to the imagined darker appearance of Hindustanis in contrast to Iranians, as the outward manifestation of mental and moral capacity.

${ }^{28} \mathrm{He}$ mentions incidents from the reigns of Manuchehr, Kayqobād, Eskandar, Ardashir, Bābak, and Khosrow I (Hazin, p. 272). He also refers to a story about Zahhāk and Hindustan in what he calls Târikh-e majus (History of the Magi); p. 273). This timeless paradigm is an example of what Babayan has called Persianate cyclical time. 
betrayal by the Hindustani friend. ${ }^{29}$ Furthermore, Nāder Shah's invasion was brought on by the treachery of the Hindustanis themselves, and even Nāder Shah, now a representative of Iranian kingship, acted with nobility and friendship (Hazin, pp. 275-78, 280-81). These representations of Nāder are in stark contrast to Hazin's general disapproval of Nāder as a brutal, base and usurping ruler. While certainly a product of the immense personal losses and hardships he suffers, not the least of which is the death and dispersal of his entire family, friends and social world, it is, significantly, in the language of ethics, of moral states and noble manners demonstrated in the faithful fulfillment of oaths and obligations (or lack thereof) that he narrates the mirrored events of Iran and his life.

Hazin's text is an elegy for the Iran he has lost and, as such, meanings governing the text position Hindustan as utterly abominable, against which the entirety of the lost past is set in opposition. But it is not just Hindustan that is devoid of virtue; it is the entirety of the present. Hazin continually states his sorrow, rage and frustration at the disorder, hardships and oppression suffered by the people and the destruction and havoc wrought upon the land and cities of Iran. Upon returning to Isfahan after the expulsion of the Afghans, he notes that "in spite of the presence of the king [Tahmāsp II], the city seemed extremely ruined and desolate (kharāb) to me and hardly anyone remained of all those people and friends" (Hazin, p. 237). He goes to Shiraz where he finds the situation much the same. Because of the sad state of his deceased friends' families and the hardships of the people, he finds it difficult to remain there (pp. 238-40). Finding similar situations in Shiraz and Lār, he comments, "the laws and regulations have fallen to pieces and there was need for a king possessing power and ability" to tend to the condition of each town and village and restore the country (molk) to a sound state. Hazin notes that "in this short time [since the expulsion of the Afghans] none of this had happened"; then he adds, "In all the places on the face of the earth there is no ruler that has the virtue (salähiyat) of rulership," except for "some of the rulers of the kingdoms of Europe ( farang), who are constant (ostovarr) in their laws, ways of livelihood and administration of their affairs" (p. 240). In the spirit of indirect criticism (Nāder was still alive at the time of writing), Hazin has not only excluded the Shah of Hindustan from the category of virtuous rulers, but also the current ruler of Iran. These descriptions need to be kept in mind when considering his

29 Though he acknowledges the Mughal kings' venerable and exalted descent from Timur, Hazin also elaborates on their murderous and injurious behavior, which resulted in the oppression of people under their rule and eventually a great fall in their fortunes. The exception to this rule was Hosayn Mirzā Bāyqarā, the ruler of Herat (Hazin, pp. 270 f.). 
denigration of Hindustan, which relies on contrast not with the contemporary Iran, but the eulogized, perfect Iran of yesterday.

By the end of the memoir, which concludes with the death of Shah Tahmāsp II at the hands of Nāder Shah's son, a number of concepts coalesce around the two poles of the past and the present. The present is Hindustan, where one is in exile as opposed to being at home. Exile is characterized by aloneness because one is a stranger, as opposed to home where one has the intimacy of friends. Alongside his frequent illness, ${ }^{30}$ various natural disasters and disgust with the way of things in Hindustan, is Hazin's constant mention of being alone. This aloneness is not literal, but indicates the absence of a people of moral integrity, learning and discernment i.e. ethical people. When he arrives in the port of Thatta, at the mouth of the Indus, and despite his desire to remain anonymous, he is unable to avoid "a group of merchants from that region [Sindh] who had met [him] in Fars... and a group of people from Iran (az ahl-e Irān)" who were resident in Sindh (p. 259). It is not that he does not want friends, but that solitude is preferable to social entanglements that are not actually friendships. Hazin states that since he has arrived in Hindustan, "the difficulty and sorrow of aloneness and forlornness (so ubat o gham-e tanhä $i$ o bi-kasi)" has always been the companion (mosäheb) of his time. The lengthy visits of various worldly people (ansāf-e khalq-e ruzgār) leave him drained in body and soul (tan o jān godäkhta; pp. 259-60). Missing are people with moral integrity, people who are not caught up in and seduced by worldly wealth and position.

Being from Iran is not enough to qualify as a person of worth, as a peer, a friend, who can ease loneliness. Hazin is alienated from those around him because the ethical union of morality and comportment, not just a geographical place, defines him. Home cannot be found in Hindustan, in the present, though there are many people from Iran. For instance, Hazin traveled to Hindustan with 'Aliqoli Dāghestāni, better known as Vāleh (1712-56), and hid in his house during Nāder's occupation of Delhi, but never once mentions Vāleh, whose acquaintance he made in Iran after the rise of Nāder Shah. ${ }^{31}$ Indeed, Hazin's invectives against Hindustan include those who come to it and are seemingly insensible to its horrors, displaying low morality through acceptance of worldly position.

That person who has a place of residence (maqām-e eqāmat-i) like the domains of Iran (mamälek-e Irān), which, delightful in essence and noble in presentation, is

${ }^{30}$ In spite of his lamentations of ill health, Hazin somehow managed to live until the age of seventy-eight. This lamentations begin with the fall of Isfahan.

31 I address this relationship at length in my forthcoming dissertation. For Vāleh's account of their meeting and his criticism of Hazin, see Vāleh, I, pp. 633-34. 
the most beneficent and perfect habitation in the known world, can never choose to reside in Hindustan. The disposition [of such a person] is formed by nature such that other than from the condition of necessity, they would never consent to stay in this land (sarzamin). And this point is shared by kings and commoners and soldiers and such is the condition of all who being of sound faculties, who have been reared in a different air and climate, especially in Iran or Ottoman (Rum) domains, unless they have come ignorant and uninformed to this region (diär) and do not have the power of return. Or, if they, on account of difficulties and accidents, no longer have the opportunity of residing in a place and have passed the preceding days with complete difficulty and wretchedness, arrive at the unbelievability (bi-étebār) of wealth and position ( $m \bar{a} l o j \bar{a} h)$ and, being of extremely weak sensibilities and base (sefla) manners, become attached (del ba ān bandad) to that [wealth and position] and gradually becoming accepting of habits/practices ('ádat), grow familiar and tranquil (Hazin, pp. 272-73).

According to Hazin, no one who has lived in other places in the world, especially in lands like Iran and Rum that stand in direct contrast, could possibly choose to live in Hindustan. Some physical calamity or spiritual deficiency would have to force them to stay. But it is the latter, the spiritual deficiency, that also takes away a person's ability to see the truth of the place around him, as he succumbs to its corruption. Hazin is one of the former-one who has come ignorant of the nature of the place and been unable to go back. But other Iranians in Hindustan, who have accepted patronage and service to the Mughal king, are those of weak sensibilities, succumbing to the inherent corrupting influence of the land. In criticizing other Iranians in Hindustan, Hazin's own suffering and forlornness are expressions of ethical righteousness. For Hazin, home is not his contemporary Iran or her people; home is the place where the social world of his youth resided, a place characterized by just government and populated by morally upright people who are now dead. With them, possibility of home is also dead.

\section{Narrating the Mughals: Kings, Countries and Agreeing on how to Disagree}

As a resident of the Mughal imperial capital, not unexpectedly, Kashmiri has a different view of the Mughals and their relationship to the Safavids than Hazin. Kashmiri downplays the centrality of the relationship with the Safavids to Mughal rule in Hindustan. He begins his account of the Mughals, whom he describes as "the sons (awläd) of his majesty the Lord of the Auspicious Conjunction, the conqueror of the world, Amir Timur Gurkān" to whom came "the rule of Hindustan (saltanat-e Hendustän)," with "Zahir-al-Din Mohammad Bābor Pādshāh, who killed Sultan Ebrāhim Lodi the king of 
Delhi and took possession of Hindustan.” Kashmiri then turns to Homāyun, Bābor's heir and successor, who "conquered and administered Hindustan, from Badakhshan to the edge of Bengal and from Gujarat to the mountain of Kumaun by the force of his sword" (Kashmiri, p. 215). In the midst of this prosperity, Homāyun suffered betrayal and then military defeat at the hands of one of his lords, Shir Khan Afghān and then his own brothers. After much hardship, he flees to "Iran and Iraq" to the presence of the Safavid Shah Tahmāsp I and "they became brothers to each other and he [Homāyun] returned [home] with the help of the Shah" (ibid). ${ }^{32}$ Homāyun is described as fulfilling an oath to take back Qandahār by force from his hypocritical (monäfeq) brothers, after which he gave the Safavid army leave to return home and wrested back Kabul from his brother Kāmrān Mirzā on his own. This victory in Kabul, where he regains the mantle of kingship, and the subsequent reconquest of the climes (eqlim) of Hindustan serve to establish Homāyun as a king in his own right. The Safavid army helped Homāyun conquer Qandahār, an important staging point, but not one integral to his rule, as were Kabul and Hindustan (Kashmiri, pp. 215-16). ${ }^{33}$ It was critical to emphasize that Homāyun regained the reigns of kingship with the help, but not the instrumentality, of the Safavid king, which would have diminished his status as Tāhmasp's brother and equal.

The Bayān's account quickly glosses over the reigns of Akbar and Jahāngir as merely setting the stage for the most significant rulers of this line, Shāhjahān and 'Ālamgir. ${ }^{34}$ Shāhjahān is titled "the second Lord of the Auspicious Conjunction," indicating that like his illustrious ancestor Timur, he was also a world conqueror and a $g h \bar{a} z i$ (religious warrior), a designation granted only to Shāhjahān and 'Alamgir. ${ }^{35}$ "During the latter's just reign, the equitable exercise of government in all matters in whole and in part [caused] the splendor of the empire, the cultivation and inhabitation of Hindustan to arrive at such a place

32 This reference to Iraq is almost certainly to 'Erāq-e 'Ajam (Persian Iraq), and the reference to Iran is likely to Khorasan, where Homāyun spent time on his way to Qazvin. Many IndoPersian texts refer to Iran as velayat, which I suspect began as a reference to Khorasan.

33 Kabul was significant because it was part of the Timurid heartlands, where Bābor ruled before launching his conquest of Hindustan. Safavid aid was given to Homāyun's endeavor, but formal suzerainty of Qandahar lay with Shāh Tahmāsp.

34 Akbar became king through the exertions of his good servant, Bayram Khān-e Khānān. In the middle of his reign he took over full sovereignty of Hindustan, and successfully subdued the rebelliousness of the "rajas" and the Afghans. Likewise, during the reign of Jahāngir, "the preliminaries of royal administration and management (moqaddamāt-e zabt o nasq-e pädshāhi) increased daily, until it was time for the prosperous kingship of Shāhjahān" (Kashmiri, p. 216).

35 This was a common designation for anyone who fought wars against non-Muslims and served as a way to legitimate the act of aggression. As in the case in Ottoman wars against the Shia Safavids, sectarian differences could also provide the basis for this designation. 
that it became Heaven on earth (behesht-e ruy-e zamin) and no opposition (mokhälef-i) remained in this country," but for the far border areas. The signs of Heaven on earth are flourishing cultivation and habitation, the physical manifestations of political unity and thus unanimity under Mughal rule brought about by just (Muslim) rule. The text then goes on to outline Shāhjahān's specific exploits, such as his territorial acquisitions in the east and the south, especially the kingdoms of Bijapur and Golconda (which he calls Hyderabad) in the Deccan (Kashmiri, p. 216). Toward the end of Shāhjahān's reign, due to the ignorant/foolish and unreasonable behavior (nädāni o kam'aqli) of the crown prince, Dārā Shekuh, his youngest son, Awrangzēb (later 'Âlamgir), was forced to rise up against and vanquish his three brothers while his father still lived and held power. ${ }^{36}$ The dubious act of rebelling against one's father is justified through the need to rectify the detriment of such a crown prince, and also by what follows the "many victorious battles [won] with the aid of the lords of the land," which is "the increased splendor of the throne." The unity of the land under the strong leadership of "Âlamgir produces developments in the kingdom which position his time as the apex of Mughal rule. "During the fifty years of his rule, the springtime rose garden of Hindustan became the increasing envy of all paradisiacal gardens." Additionally, and most importantly,

In matters of religion and Islam and the ordinances of [Islamic] law (abkäm-e shar') and the traditions of the best of men [the Prophet], which, because of the deviations of Akbar Pādshāh from the temptation/instigation (eghväi) of idolaters, [there] had accrued all the defects of deviant practices. Though this matter had been ameliorated (äb-i ba ruy-i än omur ämada) somewhat compared to previous [times] during the time of Shāhjahān, it was in the reign of 'Âlamgir ghäzi that as much should and could [be done was, and] the splendor of these ordinances and regard for the bounds of [Islamic] law and Islam advanced higher than the highest degree" (Kashmiri, p. 217).

This apex, defined by military might and unity to the glory of the realm, is complimented by the implementation of true Islamic government. Contrary to modern narratives about the Mughals that exalt Akbar and denigrate 'Âlamgir, the latter's stricter adherence to what was seen as true Islam in a ruler and in rule was idealized in a text such as the Bayan, which also defends the land of Hindustan as paradisiacal, especially in the face of enemies near and

36 'Ālamgir was the regnal name of Awrangzēb, who, likely because of his demonization in recent historiography, is the only Mughal emperor not commonly referred to by his regnal name. All eighteenth-century sources call him 'Ảlamgir and for the sake of consistency, so have I. For more on similar representations of Dārā Shekuh, see Rajeev Kinra's paper in this issue. 
far. What Hindustan meant in this context is the realm of the Mughals, where those not obedient to the specifically Muslim rule of Timurid- descended Mughal rulers were as much violators of justice and order as the low-born usurper to the throne of Iran, Nāder Shah, who attacked Hindustan, sacked Delhi and ignobly brought its emperor low. Such calamities near and far would not have been possible had mayhem not broken out amongst 'Ālamgir's sons and grandsons after his death, abetted by the selfish acts of unethical nobles, which weakened the realm of Hindustan (Kashmiri, pp. 217-18).

Though their assessment of history differs greatly, both Kashmiri and Hazin agree on a dearth of wise men and ethical conduct in Hindustan. They also both evince a feeling of living in times of decline from previous, more illustrious times. Kashmiri begins his account of events in Bengal with the explanation that "in these days, because of the weakness ( $\left.z a^{\prime} f\right)$ of the rule (saltanat)" of Mohammad Shah "and the absence of unanimity (ettefäq) of his lords/commanders (omarä) with one another" the Marathas had taken over Bengal, including Hughli, the port to which Kashmiri returns from Hajj in 1743 (Kashmiri, p. 161). This theme is oft repeated in the text, of the weakness of the Mughal emperor's government due to the factional conflicts between the elites of the realm. This infighting opens the realm to outside depredations. This is underlined by the verse offered at the end of the section, "All good fortune arises from unanimity // Misfortune arises from hypocrisy (nefäq)" (p. 162). This infighting is a result of selfish motives and leads to outright treason against the Mughal rulers, causing the noble line of Timur to be dishonored. This conflation of infighting between nobles is hypocrisy, the lowest form of ethical behavior both as a person, a peer and a subject. ${ }^{37}$ Kashmiri's critique reaches a fevered pitch by the end of the text in such a way that his assessment and method of expressing the state of matters in Hindustan is, in the end, not so different from Hazin's. In the section dealing with the various seditions during the rule of 'Álamgir II, Kashmiri, writing in 1779, states that the actions of selfish and treasonous nobles have caused the rule (saltanat) of Hindustan to be ruined and that "the 400 year [old] honor (namus) of the Timurid family has been lost (bar bād rafta)" (p. 270). In selfish power grabs from the rightful sovereign and infighting amongst themselves, the lords of the realm have allowed the honor of their ruler to be violated, thus showing themselves to be thoroughly dishonorable.

37 Another instance is (Kashmiri, pp. 169 f.) when Safdar Jang is fighting against the Rohillas, Qamar-al-Din Khan saves the Rohilla chief for his own reasons, against the interests of the emperor, to preserve the alliance created by his son's engagement with 'Ali Mohammad Khan, the Rohilla chief's son. 
Kashmiri's close relationship with another migrant from Iran, Mirzā Hāshem Shirāzi, commonly called 'Alavi Khan, the doctor with whom he goes on Hajj and who treats Nāder during the journey from Delhi to Qazvin, provides a picture of both another kind of migrant from Iran, and also another type of Mughal imperial servant. 'Alavi Khan was born in Shiraz, where he grew up and received his education. He migrated to Hindustan in 1699 and received honor and position from 'Ālamgir, continuing to serve subsequent Mughal emperors. Along with Kashmiri, he left Delhi with Nāder's army, parting ways from them in Qazvin in 1741 to travel to the Iraqi shrine cities and Mecca. Afterwards, he returned to Delhi to rejoin the service of Mohammad Shah as head physician (hakim-bäshi), where he died in 1749. Alavi Khan is mentioned often in the text, as one of the few whose craft and sage advice curbed the cruelty of Nāder Shah and who was greatly honored by all the rulers he encountered in the course of his journeys with Kashmiri. ${ }^{38}$ The notice of his life appears in the text chronologically, with the event of his death (Kashmiri, pp. 248-53). It is quite long, almost longer than Kashmiri's account of the hajj, and the description of 'Alavi Khan as an educated, upright, ethical man, excellent in his craft and devoted in his service is a portrait in contrast to the selfish and unethical behaviors of Kashmiri's contemporaries. ${ }^{39}$ The manner of his presence in the text underlines that Hazin, an involuntary migrant seeking to distinguish himself from other Iranians through denigration of Hindustan, contentment in it and service to its rulers, hardly was iconic to his Hindustani contemporaries of the attitude of an emigrant from Iran toward Hindustan. This representation of 'Alavi Khan as an example of a life worth emulating, underlines the theme of betrayal and decline that underpins the Bayān. As an Iranian who was both a voluntary migrant, one who accepted service both to the Mughal emperor and to Nāder Shah, 'Alavi Khan would have fallen firmly outside of Hazin's designation of those in possession of ethical discernment. Unsurprisingly, such figures are absent from and inimical to the theme undergirding Hazin's text, which denies the possibility of ever finding home in Hindustan.

38 On Nāder's high regard for 'Alavi Khan and desire to retain his service, and the Khan's attempts to temper the Shah, see Kashmiri, pp. 112-14, 172.

39 The Bayān is not alone in its approbation of this much honored and illustrious figure. Most mid-late eighteenth century tazkeras (commemorative compendiums) of poets with a focus on Delhi describe 'Alavi Khan similarly, though he only wrote as much poetry as expected of a man of letters and high position. Primarily a physician, the figure of 'Alavi Khan as an ethical and accomplished man is the centerpiece of these entries. For instance, see Ärzu, II, pp. 1094-95, Vāleh, III, pp. 1057-58, Khalil, pp. 186-87. He is also present as a figure, along with other great men of the Persianate world, in the witty tales (latä ef) at the end of Mir Taqi Mir's memoir written in the late eighteenth century (pp. 135-36). 
Like Hazin, Kashmiri's personal experiences are narrated as firmly embedded in the volatile historical context of the times. Kashmiri's historical account picks up where Hazin's drops off with only a slight overlap. Kashmiri accepts and incorporates Hazin's account of history, which makes up the first section $(b \bar{a} b)$ of the Bayan, though they differ in the reasons for the victory of the Afghans, which Kashmiri describes as "the weakness of the realm/rule ( $z a^{\prime} f-e$ saltanat) of Shah Sultan Hosayn" (Kashmiri, p. 7). Kashmiri shows little sympathy for the fall of the Safavids, though he shows sympathy for the land of Iran and its people, subject to so many invasions and molestations (pp. 8-10). Though he does not excuse Shah Sultan Hosayn from blame for this invasion, he is scandalized by the execution of the Safavid royal family in Isfahan at the hands of the Afghan invader, Mahmud, as well as the murder "of that sinless Shah" at the hands of Mahmud's son Ashraf (p. 10)..$^{40}$ Since Kashmiri's main consensus with Hazin is about Nāder Shah, he is generally approving of Tahmāsp II (Hosayn's son) and deplores the illegitimacy of Nāder's seizure of power from him (pp. 11-14). Hazin's dislike for Nāder Shah is a result of his depredations in Iran, while that of Kashmiri is a result of Nāder's depredations in Hindustan, though he spares no effort to demonstrate the deleterious effects of his actions in Iran as well. When it comes to Nāder Shah, instead of just lifting historical facts and giving them his own meaning, as he does with the fall of the Safavids, Kashmiri directly quotes him regarding Nāder Shah, although the two disagree over the justice of many actions. Upon news of Nāder's death, he comments:

The truth is that [he] was a man brave, bold, and sagacious, in possession of determination in undertakings, and forethought. He was wholly accomplished in matters of conquering lands, [waging] battle and being obeyed in command (nafäz-e $h o k m$ ). But [excel in] governing and [creating] flourishing inhabited places ( $\bar{a} b \bar{a} \bar{d}-$ $k \overline{a r})$ he did not. And people spoke ill of him because he was wicked and foulmouthed, bloodthirsty and merciless. For the smallest offense that a wise and just ruler would not even have someone beaten with a stick, he would have [the perpetrator] beheaded. And from the content (mazmun) of Shaikh 'Ali Hazin's robä $i$, it is evident that Emām Qoli Bayg, Nāder Shah's father, was a furrier (Kashmiri, p. 177).

Kashmiri not only is familiar with Hazin's poetry, but draws on it as support for historical assertions. The fact that Hazin's poetry and prose about Hindustan, and especially Kashmir, is largely derogatory does not seem to have

40 This seems like somewhat of a contradiction, though the execution of a monarch from a venerable royal family would understandably scandalize Kashmiri's class-conscious sentiments, whereas blaming a king for an invasion due to weak rule is permissible. 
undermined his authority with Kashmiri. Kashmiri simply states his own version of matters, such as the paradise-like qualities of Hindustan and Kashmir in particular, the absurdity of Nāder's justifications for invading Hindustan and his army's culpability in the massacre in Delhi, which directly contravene Hazin's narrative. Hazin had no love for Nāder Shah, ${ }^{41}$ whose rule he considered a calamity on the people of Iran, but the lack of blunt critique (like Kashmiri's) likely also has to do with the fact that Nāder was still alive when Hazin was writing. These texts were not written in vacuums and contexts created considerations when making decisions about how to represent certain matters.

These Persianate texts contained a shared sense of home and a common understanding of the meaning of kingdoms and countries. While originating from a region or city within a particular kingdom meant something, it is imperative to distinguish this meaning from modern connotations of national identity. Kashmiri refers to Kalat alternately as Nāder Shah's birthplace (mawludgāh-e Näder Shähi) and as his homeland (vatan) and notes that Nāder indulgently allows his countrymen (ham-vatanhā-ye $k h^{w} o d$ ) to overcharge him in resupplying his household (Kashmiri, p. 94). Such indulgences are not granted anywhere else and such language is not used for any other part of Iran, or even Khorasan. Furthermore, many words like mamlakat (dominion) and vatan (homeland), that are presumed to have definite, stable and singular meanings, could and did have multiple meanings. Translated by later historians according to nationalist meanings, these words sometimes adhere to modern definitions and other times defy the mutually exclusive connotation upon which modern meanings rely. Vatan could mean home, but was also a term for a place where one takes up residence, which can be distinct from where one was born (Tavakoli Targhi, pp. 114-16). Home was not always coincident with a person's origin, a perception that was not always geographic.

The geographical history of the Persian language is instructive with respect to the relationship between kings, countries and homelands. Persian in Hindustan was not seen as a migrated language born in Iran, but as part of a shared tradition born in Eastern Iran and Transoxiana, where Persian literary culture first crystallized in the ninth and tenth centuries. Hindustani Persians saw themselves as heirs to the Ghaznavids, who sought to meld Islam with Persian notions of kingship and ethics, an endeavor that resulted in the literary production of works such as the Shähnäma, Tärikh-e Bayhaqi and the Qäbusnäma. ${ }^{42}$ Most immediately, the Mughals traced their heritage, both

41 Kashmiri corroborates that they were known to be enemies (p. 177).

42 This regional boasting is most obvious in Amir Khosrow's introduction to one of his divāns, where he reviews the regional variations of Persian in Iran and Transoxiana and claims that Persian spoken in Hindustan is sweetest because it is the closest to literary Persian (pp. 28-29, 63-64). 
genealogical (Turco-Mongol) and cultural (Perso-Islamic), to the era of Timurid rule over Transoxiana and Iran. Within decades, this rule eventually shrank to a domain defined by the centers of Bukhara, Samarkand, and Herat. ${ }^{43}$ Geographic regions, such as Hindustan, Transoxiana and Iran, were not necessarily identical with kingdoms and were sometimes ruled separately. The Timurids had historically ruled Khorasan, considered a mamlakat (dominion) of Iran, ${ }^{44}$ as well as Samarkand and Bukhara, cities within the confines of Transoxiana. Khorasan has not always been ruled with western Persian provinces. ${ }^{45}$ In geographical terms, western Safavid domains (primarily Persian Iraq) were distinct from Khorasan and the east. ${ }^{46}$

Mohammad Tavakoli Targhi claims that the territorial border demarcations resulting from Russian and British pressures on Iran throughout the nineteenth century "shifted the characterization of Iran from a confederation of territories (mamalek) to a cohesive entity (mamlakat/keshvar-e Irān). The displacement of mamālek with mamlakat marked the transition from an empire to a modern nation-state" (Tavakoli Targhi, p. 114). Such contentions overlook the interchangeable usage of the two terms in eighteenth-century Persian sources in both Iran and Hindustan. The singular mamlakat was used in reference to Iran as former Safavid domains in the context of reference to empires. It was also the geographical moniker of a land prominently featured in historical and epic literature. But it was also used to refer to the smaller dominions with their own prominent features, histories and populations that constituted the singular empire. Iran as a political unity existed before conceptualizations of modern nation-states, since the "empire" itself was a unitary political entity made up of smaller geographical, political and cultural entities. Within these smaller entities were the locations of homelands. When Hazin discusses Hindustan or Iran, he refers to it as a mamlakat (kingdom). ${ }^{47}$ But mamlakat was not just coeval with a king's domain; it could also be a smaller

43 This occurred soon after Timur's son, Shāhrokh, died in 1447. For more on Timurid rule of Iran and Transoxiana, see Manz.

44 Khorasani was a catchall term for people from Iranian lands in Hindustan and the Deccan. See Calmard, pp. 382-83.

45 In the fifteenth century, the Aq-quyunlu ruled Western and Central Iran (along with the Caucasus, northern Iraq and Eastern Anatolia) while the Timurids retained Khorasan (also ruling Afghanistan and much of Central Asia; Woods). In the eighteenth century Karim Khan Zand ruled much of Western and northern Iran, while Shāhrokh Mirzā retained the rule of Khorasan as a tributary of Ahmad Shah 'Abdāli (Perry 1979).

46 This is not to say that other regions did not exist or were not important, but these are the two largest provinces that have come to stand in for the western and eastern geographical locations of polities named Iran.

47 For instance, see Hazin, p. 265. 
dominion with a recognizable character that had its own political and administrative coherence. For Kashmiri and Hazin, Khorasan is a smaller region, a mamlakat (dominion) that can be incorporated into a saltanat (realm) and is among the mamalek (pl. of mamlakat) of Iran. Khorasan was a part of Safavid domains but is a specific province with its own coherence and thus ruled as a whole by a provincial governor. Kashmiri also recognizes this coherence and refers to slaves freed in Transoxiana as "the people of Khorasan (mardom-e Khorāsān)" who are from "the delineated areas (hodud) of Khorasan" (Kashmiri, p. 88). As Nāder leaves Ottoman dominions, Kashmiri does not say he is returning to the land of Iran, but that Nāder proceeded in the direction of 'Eräq-e 'Ajam and Khorasan, from his location in the shrine cities, or 'Eräq-e 'Arab (Kashmiri, p. 172).

The smaller dominions were recognizable places in their own right, just as the cities within them had their own character as former capitals (Herat), places of pilgrimage (Mashhad) or abodes of learning (like Shiraz) ${ }^{48}$ Referring to the fifteenth century, when the regions of Iran were not under a single rule, Beatrice Manz notes that "cities and regions had the political ability to decide their own fates and to separate from the center, and if a ruler was to stay in control he required the active consent of local forces" (Manz, p. 280). Though Manz describes a time when the central government was extremely weak, part of a tribal Turco-Mongol governing structure that the Safavid Shahs tried to strengthen, local forces remained important (Babayan). The assassination of Nāder's governor at Lār, a man whom Hazin describes as thoroughly unjust and disrespectful of local notables, is an example of an upset in the balance between local benefits derived from service to the central government and the central government's ability to garner support from local forces. The general breakdown in central government and its links to local governing elites does not mean the latter ceased to function. The impression of post-Safavid Iran as a wasteland and Mughal India rapidly falling into disorder and decay demonstrates an important similarity of viewpoint between Hazin and Kashmiri, who, in spite of their many differences, share a sole preoccupation with and decidedly regime-centric view of their respective kingdoms. For both, without the Safavids or the Mughals reigning supreme from Isfahan and Delhi respectively, those realms were in shambles. ${ }^{49}$ Both see the other kingdom in ruin, but only to a lesser degree their own. Regardless of the irrelevance of the local conditions to our imperially focused authors, each province had its own social hierarchy, political stakes, economic mainstays and mercantile flows. And these particularities were recognized in language.

48 Respectively known in both texts as dār al-saltanat (abode of rulership), Mashhad-e moqaddas (the holy), and där al-'elm (the abode of knowledge).

49 Alam and Subrahmanyam (pp. 281-290) note this position with respect to Kashmiri. 
One did not have to leave a mamlakat, a dominion in the smaller sense of the word, to be in exile from one's homeland. In his memoir, entitled Zekr-e Mir, Mir Mohammad Taqi Mir (1723-1810) calls Agra his vatan, where his great great-grandfather chose to fix his residence (tavatton ekhtiār kard) when it was the Mughal capital, after his family had emigrated from the Hejaz to the Deccan and then to Hindustan (Mir tr., pp. 3-4). Agra, not Hindustan either as a geographical (Indo-Gangetic plain) or political domain (Mughal kingdom or even $d o-\bar{a} b$ ), is his home. He explains, "Not having found any opportunities for a livelihood in my homeland (vatan), I was hastily obliged to [enter] exile (ghorbat). I made the toil of the road my intention, chose the hardships of travel, and arrived at Shahjahanabad Delhi. [Though] I strove greatly, I was not shown any compassion (shafiqi)" (Mir, p. 62). To go to Delhi is to hasten to exile ([ba] ghorbat shitäftan) and all its attendant hardships and lack of compassion or kindness (shafiqi). So though travel from Agra to Delhi is within the Mughal heartland of north India, it is still a migration from home to a state of exile that is characterized by the absence of the comforts and kindnesses of intimacy. As with Hazin and Kashmiri, for Mir associations of home are not vested in a kingdom. One could move from one city to another in the same political and geographical domain and still be in exile.

Places within a kingdom but outside one's region or city of birth or residence could be as unfamiliar and foreign as places outside a kingdom. For Kashmiri, not all of Hindustan is part of a place called home. When traveling through Bengal and Bihar, though they are part of the dominions of India (mansub), they are separate administrative and geographical regions with their own characters and governments. ${ }^{50}$ His manner of describing Bengal is not substantially different from how he describes places in Transoxiana and Iran. "Bengal is a land/dominion (molk) [of] extensive and gold producing (zarkhiz) and [possessing] abundant income. Its climate, on account of the severity of the rainfall and nearness of the great sea, is extremely humid" (Kashmiri, pp. 164-65). Writing for a Delhi audience, this is not the type of information one provides about a familiar and known place; rather it is the typical account of climate and natural resources that one provides of another mamlakat.

During the narration of his military exploits, Hazin lauds Nāder's military victories in regaining lands that once constituted the Safavid domains that were lost to various invaders. Though he does not admire Nāder as a person, this is one of the few times that Nāder acts justly.

[I]n both the confines (hodud) of Azerbaijan and the confines of their own dominions, [Nāder] fought many difficult and arduous battles with the armies of Rum

50 The particularity of different lands has been touched on with respect to administration in Alam and Subrahmanyam, 1998. 
and obtained victory every time. Many commanders and soldiers without number from Rumis were slain in those dominions (mamälek). The fort of Yerevan, Ganja and some of the dominion (mamlakat) of Georgia and those delineated areas (hodud) that had remained in their [Rum's] possession, were wrested (entezā) [back] and nothing of the kingdom of Iran (mamlakat-e Irān) remained in the control of that group (án jamäat) (Hazin, p. 267).

For Hazin there is a specific notion of what dominions should be ruled by the throne of Iran and those are lands that once were ruled by and owed their loyalty to the Safavid throne. Thus for Hazin, the idea of Iran as a mamlakat is not some timeless notion of epic history, but the recent, historically specific Iran as constituted under the Safavid monarchs. Kashmiri shares similar notions in "description of the four boundaries of the dominions of Iran" (bayān-e hodud-e arba'a-ye mamālek-e Irān), stating, "under the rule of Iran (saltanat-e Irān) there are dominions (molk) like Khorasan, Persian Iraq, Fārs, Azerbaijan, Mazandaran and each dominion/land (molk) is comprised of several cities (shahr) and towns (qasba)." This kingdom is outlined to the east by Sindh, Kabul, Transoxiana and Khvārazm; to the west by Shām and lands of Rum; to the north by the Arxes, Circassia, and the plain of Qipchaq; and to the south by the Arabian peninsula; Kashmiri, p. 102). Hazin attributes more land as the rightful territory of the Iranian throne than Kashmiri does, but these differences are according to the parameters of territories long disputed with the Mughals, such as Qandahār. Otherwise, but for Georgia, Kashmiri shares Hazin's Safavid-based vision of what dominions constitute the kingdom of Iran.

In describing the formal enthronement of Nāder as Shah on the plain of Mughān in Azerbaijan, Hazin notes that Nāder "summoned great men, village heads (kadkhodàyann), elders (rish-safidān) from all of the cities of the dominions of Iran (jami'-i belād-e mamālek-e Irān)" (Hazin, p. 268). The realm of Iran is both a mamlakat, and is made up of smaller parts identically described as mamlakat. Similarly, when Kashmiri describes the departure of Nāder Shah from Delhi, when he reconfirms Mohammad Shah as the king of Hindustan, he literally says that Nāder "consigned the kingdom of Hindustan to Mohammad Shah" (Kashmiri, p. 45). The word used for kingdom is not neatly interchangeable with a Safavid or Mughal realm, since it is also a word for the provinces that these kings indirectly ruled, in part or in whole, through various governors. The meaning of mamlakat is not neatly coincidental with a modern sense of an Iranian or Indian nation-state, proto or otherwise, since the meaning of the word contains decentralized alternate meanings that undermine this equivalence.

Though Persian in Iran would be formed by an ever-narrowing cannon of classics from the end of the eighteenth century onwards, a Persian Hindustani 
like Kashmiri, who was not a poet, had access to the same literary repository of tropes and figures as Hazin. Both men make reference to Persian literary figures and personages, ranging from actual poets, to heroes, kings, statesmen, mystics and lovers. Kashmiri quotes couplets from the poets Sa'di, Rumi, and Hafez, among others, as well as referencing stories of the Shähnäma and Khosraw o Shirin to illustrate his points (e.g., see Kashmiri, p. 193). Ethical evaluations and paradigmatic possibilities were contained in this literary corpus. According to Kathryn Babayan, one prominent feature of Persianate ethos is a sense of cyclical time and being, exemplified in the Shähnäma, where "Iranian society is portrayed as encountering similar ethical dilemmas in different ages. In each era, kings are confronted with analogous situations as they attempt to rule their dominion with justice and to deal with political realities and ethical choices regarding their sons, warriors, subjects and neighbors," Transoxiana, India, and Anatolia (Babayan, p. 29). Hazin's historical narrative regarding the Safavids and Mughals certainly conforms to this cyclical sense of time and being, in the form of a parallel relationship between history and the present. Hazin explicates political events through analogy with the actions of the preIslamic kings of the Shähnäma, as well as frequent reference to Hafiz. Kashmiri displays a sense of cyclical Persianate time in his description of Mughal politics, such as in his description of the battle between Ahmad Shah Dorrāni and Mughal forces, which he likens to the battle between Bābor and Ebrāhim Afghan Lodi two hundred years before (Kashmiri, p. 210).

In spite of similarities derived from this common cultural repository of ethical and literary tropes, there were differences, too, which in the rush to foreground the cohesiveness of the Persianate are often glossed over. For one, the Persian language permeated the populations of these regions in different ways. Deployed as a language of power and government in Hindustan, Persian was a learned language of prestige and education. A high Persian literary education was certainly beyond the grasp of most in Iran, but the language, and its poetry and epics, existed in oral forms through deeper strata of society. Persian did not have the same sort of competition as a literary language in Iran as it had in Hindustan, where Hindavi, regional languages and Sanskrit had a significant presence. ${ }^{51}$ Regional style, standards and idioms were results of differences in the way Persian as a literary language developed in Iran and Hindustan, a development directly linked to political, social and cultural contexts. Irāni Persian regional literary concerns within the Persianate is something that we can ascribe to Shi'ism as it developed after being adopted by the

${ }^{51}$ However, the presence of these languages as literary languages existed to differing degrees and was used for specific purposes. For instance, a Hindu might be as likely to write devotional poetry in Sanskrit as in Persian, depending on his position, education and location. 
Safavids as part of their imperial ideology. For example, qasidas written in praise of the twelve Imams were a subgenre of poetry that flourished in Iran, ${ }^{52}$ just as tazkeras produced under Safavid patronage were different from those produced for the Mughals (Sharma, forthcoming). ${ }^{53}$ These points are nothing new; what I want to point out is that the terms that have been used to discuss differences trap these discussions into nationalist frameworks that distort the nature of differences into the polar oppositions by which nationalism defines itself. It also assumes an anachronistic relationship between language, geography and subjective identity. Calling Persian a native language or mother tongue of Iran and a foreign language in Hindustan evokes meanings for these terms that are unhelpful for understanding the different social experiences of Persian that led to cultural variation, and sometimes conflict, within the Persianate world.

The fall of the Safavids as an event (the way it is imagined and interpreted) is central to changing interactions between Iranian emigrants and travelers from Iran and Hindustan. This event created a whole group of refugees to Hindustan. The outcome of this event also led to the devastation of north India under Nāder Shah. Hazin's memoir is a text of elegy and exile, and Kashmiri's travelogue is a text of pilgrimage and historical explanation for the weakening of the Mughal center. In addition to historical context, differences that shape the texts are related to place of origin. Within the Persianate world, Hindustan is a land of worldly wealth and Iran is part of the Islamic heartlands, though these geographical characteristics can be given different meanings. Therefore, movements from South Asia toward the Middle East in the accounts usually are written as a pilgrimage to a sacralized heartland, via Iran. Movements from Iran to Hindustan are usually written as movement away from this heartland, of which most Iranians saw themselves a part. Travel to Hindustan was seen, even under voluntary circumstances, as to a place less spiritually pure and in possession of more worldly wealth. This is the case even for Kashmiri, who is at pains to detail the Islamification of Mughal rule under 'Ālamgir and whose depiction of Transoxiana, Iran, Iraq and Hejaz is peppered with Koranic prophets, early Islamic saints, and figures foundational to PersoIslamic culture (such as Avicenna's grave in Hamadan). Under involuntary

52 This was a genre that often distinguished the Iranians no matter where they went or whose patronage they enjoyed; see the qasidas of Nurallāh Shushtari, Mohammad Sa id "Ashraf" Māzandarāni, Hazin, and Lotf 'Ali "Āzar" Baygdeli.

53 This distinction becomes much more complicated when considering that many Mughal commissioned tazkeras were written by Iranian migrants. Distinctions become muddled even further when we consider that most tazkeras in the eighteenth century were written without royal patronage and reflect more individual visions of cultural community, often accumulations of Safavid- and Mughal-centric concerns. 
circumstances, especially when the heartland is destroyed, Hindustan was seen as a place of exile, where one was a stranger, and thus inherently an inferior place to home, a sense made all the more acute by the impossibility of return to a place that no longer exists. ${ }^{54}$

In spite of their differences, Hazin and Kashmiri share many views. They experienced the invasion of their respective kingdoms and cities, which both view as calamities. They share many of the same historical evaluations: a dislike and disdain for Nāder Shah, a sense of political decline in their respective kingdoms, ruin in surrounding lands and admiration for Europeans. But more importantly, they also represent these with similar cultural valuations, voicing judgments about politics and culture cyclically and ethically, through historical parallels and in the language of loyalty and friendship. Their common Persian cultural repository made possible textual borrowings that expressed differing, sometimes conflicting, attributions of cultural valuation and historical meaning. Differences of opinion were not viewed as differences of culture by the authors themselves, but as differences over meaning within a common culture.

\section{References}

M. Alam and S. Subrahmanyam, Indo-Persian Travels in the Age of Discoveries, 1400-1800, Cambridge, 2007.

Idem, "The Making of a Munshi," Comparative Studies of South Asia, Africa and the Middle East 24/2, 2004, pp. 381-416.

Idem, "Introduction," in M. Alam and S. Subrahmanyam, eds., The Mughal State: 1526-1750, New Delhi, 1998, pp. 1-71.

Amir Khosrow Dehlavi, Dibācha-ye divān-e ghorrat al-kamāl, ed. Vazir al-Hasan 'Abedi, Lahore, 1975.

Serāj-al-Din 'Ali Khan Ārzu, Tazkera-ye majma' al-nafä̀es I, ed. Zēb-al-Nesā' 'Ali Khan, Islamabad, 2004; II, ed. Mehr Nur Mohammad Khan, Lahore, 2006.

M. Axworthy, The Sword of Persia: Nāder Shāh, from Tribal Warrior to Conquering Tyrant, London, 2006.

K. Babayan, Mystics, Monarchs, and Messiahs: Cultural Landscapes of Early Modern Iran, Cambridge, 2002.

J. Calmard, "Safavid Persia in Indo-Persian Sources and in Timurid-Mughal Perception," in M. Alam, F. Delvoye and M. Gaborieau, eds., The Making of Indo-Persian Culture: Indian and French Studies, New Delhi, 2000, pp. 351-91.

J. Cole, "Mirror of the World: Iranian 'Orientalism' and early 19th-century India," Critique, Spring 1996, pp. 41-60.

Mohammad 'Ali Hazin Lāhiji, Tārikh o safarnāma-ye Hazin, ed. 'Ali Davvāni, Tehran, $1375 / 1996$.

${ }^{54}$ For the figure of the stranger, see Rosenthal. I thank Naghmeh Sohrabi for bringing this article to my attention. 
'Abd-al-Karim Kashmiri, Bayān-e vāqe': sargozasht-e ahvāl-e Näder Shāh o safarhāa-ye mosannef, ed. K.B. Nasim, Lahore, 1970.

'Ali Ebrāhim Khan Khalil Banārasi, Sohof-e Ebrāhim. bakhsh-e mơāserān, ed. Mir Hāshem Mohaddeth, Tehran, 1384/2005.

S.K. Khatak, Shaykh Muhammad'Ali Hazin: His Life, Times and Works, Lahore, 1944.

M. Kia, "Paradoxes of Circulation and Hybridity: Joseph Emin's Cultural Idioms of Self and Nation," paper read at the sixth ISIS conference, London, 2006.

R. Kinra, "The Place of Place in Early Modern Indo-Persian Comparative Philology," paper read at the seventh ISIS conference, Toronto, 2008a.

Idem, "Secretary-Poets in Mughal India and the Ethos of Persian: The Case of Chandar Bhan Brahman," Ph.D. dissertation, University of Chicago, 2008b.

L. Lockhart, Nadir Shah: A Critical Study based mainly on Contemporary Sources, London, 1938.

A. Loewen, "Proper Conduct (Adab) is Everything: The Futuwwat-namah-i Sultani of Husayn Va iz-i Kashifi," Iranian Studies 36/4, 2003, pp. 543-70.

P. de Man, "Autobiography as De-facement," MLN 94/5, 1979, pp. 919-30.

B.F. Manz, Power, Politics and Religion in Timurid Iran, Cambridge, 2007.

B.D. Metcalf, "Introduction," in Moral Conduct and Authority: The Place of Adab in South Asian Islam, ed. B. D. Metcalf, Berkeley, 1984, pp. 1-20.

Mir Taqi Mir, Zekr-e Mir, ya'ni hazrat-e Mir Taqi Mir ke khwod nevesht savāneh-e 'omri, ed. 'Abdal-Haqq, Awrangabad, 1928; English tr. by C.M. Naim as Zikr-i Mir: The Autobiography of the Eighteenth Century Mughal Poet Mir Mohammad Taqi "Mir,"New Delhi, 1999.

R. O'Hanlon, "Manliness and Imperial Service in Mughal North India," Journal of the Economic and Social History of the Orient 42/1, 1999, pp. 47-93.

J.R. Perry, "The Historical Role of Turkish in Relation to Persian of Iran," Iran and the Caucasus 5, 2001, pp. 193-200.

Idem, Karim Khan Zand: A History of Iran, 1747-1779, Chicago, 1979.

J.F. Richards, "Norms of Comportment among Imperial Mughal Officers," in B.D. Metcalf, ed., Moral Conduct and Authority: The Place of Adab in South Asian Islam, Berkeley, 1984, pp. 255-89.

F. Robinson, "Perso-Islamic Culture in India from the Seventeenth to the early Twentieth Century," in R.L. Canfield, ed., Turko-Persia in Historical Perspective, Cambridge, 1991, pp. 104-31.

F. Rosenthal, “The Stranger in Medieval Islam," Arabica 44/1, 1977, pp. 35-75.

Sa'di, Golestān, tr. Wheeler M. Thackston as The Gulistan (Rose Garden) of Sa'di, Bethesda, 2008.

M. Shafi', "Abd-al-Karīm Kashmīrī”, $E I^{2}$.

M.-R. Shafi i-Kadkani, Shäer-i dar hojum-e montaqedān. naqd-e adabi dar sabk-e Hendi: pirāmun-e shèr-e Hazin-e Lähiji, Tehran, 1375/1996.

S. Sharma, "The Land of Darkness: Images of India in the Works of Some Safavid Poets," Studies on Persianate Societies, 2003, pp. 97-110.

Idem, "Amir Khusraw, Fayzi and the Geography of Indo-Persian Literature," forthcoming.

M. Tavakoli Targhi, Refashioning Iran: Orientalism, Occidentalism and Historiography, London, 2001.

R. Travers, Ideology and Empire in Eighteenth Century India: the British in Bengal, Cambridge, 2007.

E.S. Tucker, Nadir Shah's Quest for Legitimacy in post-Safavid Iran, Gainesville, 2006.

'Ali Qoli Vāleh Dāghestāni, Tazkera-ye riyāz al-sho'arā', ed. Sayyed Mohsen Nāji Nasrābādi, 4 vols., Tehran, 1384/2005.

J.E. Woods, The Aqquyunlu: Clan, Confederation, Empire, Salt Lake City, 1999. 